\title{
An overview of disaster management in India
}

\author{
A. J. Shah \\ Applied Mechanics Department, S V National Institute of Technology, \\ Surat, Gujarat, India
}

\begin{abstract}
India is one of the hazard prone countries in South Asia. Floods, droughts, landslides, snowstorms, hurricanes and cyclones occur regularly. Among these earthquakes, floods and drought risk are extremely high. These hazards threaten millions of lives and cause large scale financial, infrastructure, agriculture and productivity losses that seriously hinder India's overall development. In India, as in the United States, the primary responsibility for responding to disaster lies at the state and the central level. The GOI have a national emergency plan for disaster management, some of the state also has a disaster management plan. It can be, and is called upon to assist when necessary, but there is a lack of awareness in the public. Many Indian States have limited resources and lack their own disaster management plans. Considering these problems, this paper attempts to throw light on a more integrated and responsive disaster management system in India. This paper will provide important information in three mutually reinforcing areas viz. disaster preparedness, response and rehabilitation management. The various case studies for disaster management will be discussed.
\end{abstract}

Keywords: disaster, mitigation, hazards, risk, safety management, India, Gujarat, Surat, Gir, students.

\section{Introduction}

\subsection{What is disaster?}

Disaster is a sudden, calamitous event bringing great damage, loss, and destruction and devastation to life and property. The damage caused by disasters is immeasurable and varies with the geographical location, climate and the type of earth surface/degree of vulnerability. This influences the mental, socio- 
economic, political and cultural state of the affected area. Generally, disasters have the following effects in the concerned areas

i) It completely disrupts the normal day-to-day life.

ii) It negatively influences the emergency systems.

iii) Normal needs and processes like food, shelter, health, etc. are affected and deteriorate depending on the intensity and severity of the disaster.

It may also be termed as "a serious disruption of the functioning of society, causing widespread human, material or environmental losses which exceed the ability of the affected society to cope using its own resources."

Thus, a disaster may have the following main features:

Unpredictability, Unfamiliarity, Speed, Urgency, Uncertainty, and Threat.

Thus, in simple terms we can define disaster as a hazard causing heavy loss to life, property and livelihood, e.g. a cyclone killing 10,000 people, or a crop loss of one crop can be termed as disaster.

\subsection{Types of disaster}

Generally, disasters are of two types - natural and manmade. Based on the devastation, these are further classified into major/minor natural disaster and major/minor manmade disasters. Some of the disasters are listed in Table 1 below.

Table 1: $\quad$ Types of disaster.

\begin{tabular}{|c|c|}
\hline Major natural disasters & Minor natural disasters \\
\hline $\begin{array}{ll}\text { - } & \text { Flood } \\
\text { - } & \text { Cyclone } \\
\text { - } & \text { Drought } \\
\text { - } & \text { Earthquake }\end{array}$ & $\begin{array}{ll}\text { - } & \text { Cold wave } \\
\text { - } & \text { Thunderstorms } \\
\text { - } & \text { Heat waves } \\
\text { - } & \text { Mud slides } \\
\text { - } & \text { Storm } \\
\end{array}$ \\
\hline Major manmade disaster & Minor manmade disaster \\
\hline $\begin{array}{ll}\text { - } & \text { Setting of fires } \\
\text { - } & \text { Epidemic } \\
\text { - } & \text { Deforestation } \\
\text { - } & \text { Pollution due to prawn } \\
\text { cultivation } \\
\text { - } \\
\text { - } \quad \text { Wars }\end{array}$ & $\begin{array}{ll}\text { - } & \text { Road / train accidents, riots } \\
\text { - } & \text { Food poisoning } \\
\text { - } & \text { Industrial disaster/ crisis } \\
\text { - } & \text { Environmental pollution }\end{array}$ \\
\hline
\end{tabular}

\subsection{Risk}

Risk is a measure of the expected losses due to a hazardous event of a particular magnitude occurring in a given area over a specific time period. Risk is a function of the probability of particular occurrences and the losses each would cause. The level of risk depends on: 
i) Nature of the hazard

ii) Vulnerability of the elements which are affected

iii) Economic value of those elements.

\subsection{Vulnerability}

It is defined as "the extent to which a community, structure, service, and/or geographic area is likely to be damaged or disrupted by the impact of particular hazard, on account of their nature, construction and proximity to hazardous terrain or a disaster prone area"

\subsection{Hazards}

Hazards are defined as "Phenomena that pose a threat to people, structures, or economic assets and which may cause a disaster. They could be either manmade or naturally occurring in our environment."

The extent of damage in a disaster depends on:

i) The impact, intensity and characteristics of the phenomenon and

ii) How people, environment and infrastructures are affected by that phenomenon.

This relationship can be written as an equation:

$$
\text { Disaster Risk }=\text { Hazard }+ \text { Vulnerability }
$$

\section{Overview of the Disaster Risk Management Programme}

The Government of India (GOI), Ministry of Home Affairs (MHA) and United Nations Development Programme (UNDP) signed an agreement in August 2002 for the implementation of "Disaster Risk Management" Programme to reduce the vulnerability of the communities to natural disasters, in identified multihazard disaster prone areas.

Goal: "Sustainable Reduction in Natural Disaster Risk" in some of the most hazard prone districts in selected states of India".

The four main objectives of this programme are:

1. National capacity building support to the Ministry of Home Affairs.

2. Environment building, education, awareness programme and strengthening the capacity at all levels in natural disaster risk management and sustainable recovery.

3. Multi-hazard preparedness, response and mitigation plans for the programme at state, district, block and village/ward levels in select programme states and districts.

4. Networking knowledge on effective approaches, methods and tools for natural disaster risk management, developing and promoting policy frameworks. 


\subsection{Disaster management in India "Government of India" [1]}

"Ministry of Home Affairs":

i) A review of the disaster management mechanism was carried out by the Government of India after the Bhuj earthquake. It was noted that there was need for building up holistic capabilities for disaster management - so as to be able to handle both natural and man-made disasters. It was accordingly decided that the subject of Disaster Management be transferred from the Ministry of Agriculture to the Ministry of Home Affairs (excluding drought and epidemics and those emergencies/disasters which were specifically allotted to other Ministries).

ii) India has been very vulnerable to natural hazards and calamities. The Bhuj earthquake accounted for 13,805 deaths, the super cyclone in Orissa accounted for 9,885 deaths. The Government are of the view that if appropriate mitigation measures had been taken these casualties could have been reduced significantly.

iii) Each year disasters also account for the loss of thousands of crops in terms of social and community assets. It is clear that development cannot be sustainable without building in mitigation into the planning process. Keeping the above factors in view, the Government of India have brought about a change in policy which emphasizes mitigation, prevention and preparedness. A strategic roadmap is prepared on the succeeding pages that has been drawn up for reducing the country's vulnerability to disasters. Action for reducing our vulnerabilities to disasters shall be taken in accordance with the roadmap. The roadmap will be reviewed every two years to see if any change in direction is necessary.

A Disaster Management Plan in India includes the following:-

- Institutional and policy framework;

- Early warning system;

- Disaster prevention and mitigation;

- Preparedness.

\subsubsection{Institutional and policy framework}

- The institutional and policy mechanisms for carrying out response, relief and rehabilitation have been well-established since Independence. These mechanisms have proved to be robust and effective insofar as response, relief and rehabilitation are concerned.

- At the national level, the Ministry of Home Affairs is the nodal Ministry for all matters concerning disaster management.

- National Crisis Management Committee (NCMC).

- Crisis Management Group.

- Control Room (Emergency Operation Room).

- Contingency Action Plan.

- State Relief Manuals Funding mechanisms. 


\subsubsection{Early Warning System}

- Cyclone.

- Indian Meteorological Department (IMD) is mandated to monitor and give warnings regarding Tropical Cyclone (TC). Monitoring process has been revolutionized by the advent of remote sensing techniques. A TC intensity analysis and forecast scheme has been worked out using satellite image interpretation techniques which facilitate forecasting of storm surges.

- The meteorological satellite has made a tremendous impact on the analysis of cyclones. INSAT data has also been used to study the structures of different TCs in the Bay of Bengal. IMD is also producing Cloud Motion Vectors (CMVs). Very High Resolution Radiometer (VHRR) payload onboard INSAT -2E which have been improved upon to provide water vapour channel data in addition to VIS and IR onboard INSAT - 2E. A separate payload known as Charged Couple Device (CCD) has also been deployed onboard this satellite.

- Flood.

At present there are 166 flood forecasting stations on various rivers in the country which includes 134 level forecasting and 32 inflow forecasting stations, river-wise break up. The flood forecasting involves the following four main activities:

i) Observation and collection of hydrological and hydro-meteorological data.

ii) Transmission of data to forecasting centres.

iii) Analysis of data and formulation of forecast.

iv) Dissemination of forecast.

For other natural disasters specific early warning systems are under progress.

\subsubsection{Disaster prevention and mitigation}

The Government of India have adopted mitigation and prevention as essential components of their development strategy. The Tenth Five Year Plan document has a detailed chapter on Disaster Management.

The Government of India have issued guidelines that where there is a shelf of projects, projects addressing mitigation will be given a priority. Measures for flood mitigation were taken from 1950 onwards. As against the total of 40 million hectares prone to floods, an area of about 15 million hectares has been protected by construction of embankments.

A National Core Group for Earthquake Mitigation has been constituted consisting of experts in earthquake engineering and administrators.

A Disaster Risk Management Programme has been taken up with the assistance from UNDP, USAID and European Union in 169 most hazard prone districts in 17 States including all the 8 North Eastern States.

Under this programme disaster management plans have been prepared for about 3500 villages, 250 Gram Panchayat, 60 blocks and 15 districts. 


\subsubsection{Preparedness}

Mitigation and preparedness measures go hand-in-hand for vulnerability reduction and rapid professional response to disasters.

The Central Government is now in the process of training and equipping 96 specialist search and rescue teams, each team consisting of 45 personnel including doctors, paramedics, structural engineers, etc.

A 200 bedded mobile hospital, fully trained and equipped is being set up by the Ministry of Health and attached to a leading Government hospital in Delhi. The Geographical Information System (GIS) data base is an effective tool for emergency responders to access information in terms of crucial parameters for the disaster affected areas.

\subsection{Gujarat State Disaster Management Policy (GSDMP)}

The Gujarat State Disaster Management Policy [2] considers the understanding of hazards and disasters, their behavior, and the risks they pose to the community as fundamental to achieving successful disaster management. Thus, the strategy for implementing the GSDMP emphasises an integrated approach to disaster management, covering the following phases of managing disasters as essential components of any disaster management program: Pre, Impact and Post disaster phase.

In order to carry out the prescribed activities contained within this policy, the GoG has defined a framework of operation for a set of agencies that play a key role in disaster management. The GSDMP envisages a DM framework where the following entities play significant roles:

- Gujarat State Disaster Management Authority.

- State Relief Commissioner.

- Government departments.

- District Administration, headed by the District Collector.

- Local Authorities, including Municipal Corporations, District, Talukas, Gram Panchayats etc.

- Voluntary agencies, including NGOs.

- Public sector, private sector; community.

The implementation framework is based on the premise that disaster management is not a separate sector or discipline but an approach to solving problems that facilitates disaster management, harnessing the skills and resources across stakeholders. Therefore, a key element of the policy framework is to leverage the resources and capability of existing entities and build new capabilities, wherever necessary. While for most activities, the implementation agencies remain the local authorities and Government functionaries, at the state level, GSDMA provides the overall direction and guidance that keeps the focus of various entities on disaster management. 


\subsection{Mumbai (Metro Polyton City), India Disaster Risk Management profile}

Functional arrangements. Consistent with the national approach, Mumbai's Disaster Management Plan [3] refers to its goals of mitigation strategy as:

- To substantially increase public awareness of disaster risk so that the public demands safer communities in which to live and work.

- To significantly reduce the risks of loss of life, injuries, economic costs, and destruction of natural and cultural resources that result from disasters.

- Inter-City Linkages.

- Land Use Management.

\subsubsection{Vulnerability issues}

- Fire and industrial accidents have been part of the landscape of the city.

- Floods. Mumbai DMP identifies 10 sections along the Central Railway.

- Chemical (transport, handling), biological, and nuclear hazards.

- Earthquakes. Mumbai lies in the Bureau of Indian Standards (BIS) in Seismic Zone III.

\section{Case studies and conclusion derived}

\subsection{Management of earthquake}

India high earthquake risk and vulnerability is evident from the fact that about 59 per cent of India's land area could face moderate to severe earthquakes. During the period 2000 to 2010 , more than 25000 lives were lost due to major earthquakes in India, which also caused enormous damage to property and public infrastructure. All these earthquakes established that major casualties were caused primarily due to the collapse of buildings.

These emphasise the need for strict compliance of town planning bye-laws and earthquake resistance building codes in India. These guidelines have been prepared taking into account an analysis of critical gapes responsible for specific risk.

These guidelines emphasise the need for carrying out the structural safety audit of existing lifelines structures and other critical structures in earthquake prone areas, and carrying out selective seismic strengthening and retrofitting.

The earthquake guidelines rest on the following six pillars of seismic safety for improving the effectiveness of earthquakes management in India.

The following are the 6 pillars:

- Earthquake resistant construction of new structures.

- Selective seismic strengthening and retrofitting of existing priority structures and lifeline structures.

- Regulation and enforcement.

- Awareness and preparedness.

- Capacity development of education, training, R \& D, capacity building and documentation.

- Emergency response. 


\subsection{Surat, Disaster Management Plan}

The city of Surat situated in the State of Gujarat in India having population of more than 4.7 million.

Plague in Surat:

The plague became an issue of global concern. Close to 200 deaths were linked to the outbreak in Surat. The disease created widespread panic and led to a mass exodus from the city. Apart from the human tragedy, it was a severe blow to not only Surat's economy which suffered a loss of several million rupees every day, but also to the nation's economy. The outbreak had an impact on industrial production, tourism, export, and many other areas. International flights to India were temporarily suspended, and export of food grains from Surat was banned. The precipitating factor for the outbreak of plague in Surat was constant rain which lashed the city for more than two months, and led to flooding and large-scale water-logging in low-lying areas. The primary reason for this was the faulty drainage system. Hundreds of cattle and other animals died due to the flood and water-logging. The floods, in fact, only brought to a crisis point the dangers inherent in inadequate waste management systems.

Conclusion: This plague taught a lesson to the Municipal Authority, other related authorities and the general public in the city. Following the plague all the drainage systems and storm water system were improved. Systems were built for the solid waste management and cleanliness. The public became aware about the issues of cleanliness.

The flood management system was introduced; a hydrological contour map was prepared for the city. Rescue and relief services are put in order.

\subsection{The Bhopal gas tragedy}

The careless siting of industry and relatively poor regulatory controls leads to illhealth in the urban centers. The Bhopal gas tragedy on December 2nd, 1984, where Union Carbide's plant leaked 43 tons of methyl isocyanate and other substances, used in the manufacture of pesticides, is one of the worst industrial accidents in the recent past. Of the 520,000 people who were exposed to the gas, 8,000 died during the first week and another 8,000 later. The impact on the survivors is visible even today.

Conclusion: The government of India and respective state government through their pollution control board have laid down strict regulation and monitoring system for industries to avoid any such accident. Every industry is forced to have the safety measures and disaster management plan.

\subsection{Disaster management plan for GIR: a case study [4]}

Conservation values:

- Largest compact track of dry deciduous forest in the semi-arid western parts of the country.

- Rich biodiversity area supporting large number of species including several endangered species. 
- Highest concentration of top carnivores-lions and leopards (over 600), and possibly the single largest population of marsh crocodiles in the country.

- Important biological research area with considerable scientific, educational, aesthetic and recreational values.

- Mother of cultural and religious evolution in Saurastra.

During 2001 to 2006 there were about 150 incident of fire affecting small, medium and large areas. More than 70 lions died between 2001 and 2006.

Table 2: Present situation of GIR Disaster Management.

\begin{tabular}{|l|l|l|l|}
\hline $\begin{array}{c}\text { Various } \\
\text { disasters in } \\
\text { park/ their } \\
\text { action }\end{array}$ & \multicolumn{1}{|c|}{ Preparedness } & \multicolumn{1}{|c|}{ Mitigation } & Prevention \\
\hline Forest fires & $\begin{array}{l}\text { Recommended: } \\
\text { Taking } \\
\text { advantage of } \\
\text { response to } \\
\text { boost a } \\
\text { "Preparedness } \\
\text { culture". RS and } \\
\text { GIS is used }\end{array}$ & $\begin{array}{l}\text { Yes, fire } \\
\text { fighting, fire line } \\
\text { maintained, } \\
\text { local } \\
\text { participation }\end{array}$ & $\begin{array}{l}\text { Low Priority (only } \\
\text { when the risk is } \\
\text { imminent and no } \\
\text { preventive } \\
\text { multiannual } \\
\text { programme had } \\
\text { been launched on } \\
\text { time) }\end{array}$ \\
\hline Drought & $\begin{array}{l}\text { No, no per } \\
\text { meant water } \\
\text { harvesting } \\
\text { structures }\end{array}$ & $\begin{array}{l}\text { Yes, water holes } \\
\text { creation, } \\
\text { Transport of } \\
\text { water to wildlife }\end{array}$ & No \\
\hline Epidemics & $\begin{array}{l}\text { No, not any } \\
\text { special mentions } \\
\text { in existing } \\
\text { management } \\
\text { plan }\end{array}$ & $\begin{array}{l}\text { Yes, } \\
\text { Vaccination, } \\
\text { cattle prevention }\end{array}$ & No \\
\hline & No special work regarding this \\
\hline
\end{tabular}

National Disaster Management Centre (Sasan)

- Information management

- Preparation of strategies, policies and plans

- Assessing vulnerability

- Coordination and support during disaster and emergency situations

- Non-emergency situations

- Conducting audits

- Training and community awareness. 


\subsection{India tsunami [5]}

\subsubsection{Magnitude of disaster}

On December 26, 2004 the tsunami caused extensive damage in 897 villages in five states/UTs in India. During the tsunami 4,259 were Injured, 5,555 people were missing and 10,749 were dead. The major sectors affected in each state: fisheries and boats, ports and jetties, roads and bridges, power and ICT, housing, water supply and sewerage and social infrastructure.

Rescue and relief operations were adjusted to be speedy, effective and timely by the external agency i.e. undertaking debris removal and disposal of bodies, dispatching relief material, providing food, water, and medical assistance. Adopting good past practices:

- Earlier disaster management programs, done successfully, were revisited to carry forward the lessons learned.

- Encourage ownership of solutions by potential beneficiaries to ensure sustainability.

- Encourage partnerships of government, beneficiaries, community-based women's organizations and NGOs to ensure sustainable development.

- Demonstrate that project implementation can be assured through a fully empowered Project Management Unit with competent leadership.

- Address need for a long term approach to O\&M funding.

\subsection{Role of engineering student for disaster management}

A lot of the nation's older teenagers are part of 'emergency rescue teams' mostly the training goes side by side along with 'compulsory military training' programs. I would like to negate student community from search and rescue since that is a highly specialized job and should be left to professionals. The basic role of the student, in my opinion, is AWARENESS of what to do during and after disasters. This would lessen panicking, paranoid and uncontrollable people running around. Also, knowing what to do when disaster strikes will also lessen the death toll. Knowing what to do after a disaster, and at least basic first aid, will enable students to help the authorities in saving lives. If students are well trained then if there is a disaster they are able to protect themselves and they can also help others. The student branch is the most well informed branch of the community. They can spread awareness about disaster management. In addition, they can form association to help in times of disaster. Children can help in managing disasters in many ways, and students can help in rehabilitation and resettlement of victims.

- They can spread awareness through rallies in streets.

- Volunteer in the information centers and form associations for the Disaster-Day.

- Provide the victims with basic needs.

- Preventing disasters at home - stopping building fires due to petty reasons like a short circuit. 


\section{Conclusion}

Disasters are inevitable. The fact lies in stating "we must all be prepared to try to survive the current and the forthcoming disasters." We cannot rule the nature but we can at least be watchful and vigilant. The structured and preplanned preparedness and the healthy response to the disaster will help save the lives. Our success lies in, as is preached by the great people that existed and exist on earth "unity and unanimity devoid of discords."

\section{References}

[1] National Disaster Management Authorities, Government of India. www.ndma.gov.in

[2] Gujarat Disaster Management Authority, Ghandinagar. www.gsdma.org.

[3] Disaster Risk Management Profile, Mumbai, India. http://emi.pdc.org/ cities/CP-Mumbai-09-05.pdf

[4] Sasikumar K., Dhirendra Bhargava, Disaster Management Plan for GIR: IGNFA, Dehradun.

[5] Sidhu K.S., Tsunami Rehabilitation Program, Planning Commission, March 18, 2005, Manila. 